\title{
J. R. STEPHENS \\ AND THE CHARTIST MOVEMENT
}

Joseph Rayner Stephens's active participation in the Chartist movement was limited to three months in the autumn of 1838 . His Chartist career began in mid-September when he was elected as a delegate to the Convention by the men of Ashton-under-Lyne and had ended before he was arrested at the end of December. During that time he spoke at meetings not only in Lancashire and the West Riding of Yorkshire but also at places as far afield as Carlisle and Norwich. $\mathrm{He}$ was elected a delegate to the Convention at Ashton, at the great South Lancashire demonstration, at Stockport, and at Norwich. He was a commanding figure on Chartist platforms, and historians of the movement have devoted a great deal of attention to him. His vivid and forceful language, prominence in the early stages of the agitation, early arrest, and seeming recantation of Chartism all provide choice material for historians, who have been quick to exploit it. By all hands, Stephens is given credit for the part he played in arousing the working men of the North of England and for fostering in them a sense of identity to which the Chartists could appeal. This was a fundamentally important contribution to the development of the Chartist movement. But historians have not clearly raised two important questions about Stephens's role in the movement. First, did Stephens think when he was participating in the movement that its immediate goal - enactment of the People's Charter - was worthwhile? Timing is important here for many historians have noted that he renounced the movement between the time of his arrest in December, 1838 and his trial in August, 1839. Second, did his impact on the agitation extend beyond arousing the men of the North? These questions are related, for his skepticism about Chartist goals helped to shape his impact on the movement.

Some historians have touched upon these questions. Stephens's biographer, George Jacob Holyoake, asserted that Stephens did not care for the "Democratic principle", that "Chartism and the "rights of man' were not to his mind", and that he "spoke in defence of the 
People's Charter [...] because no other means seemed open whereby the people could be helped". But Holyoake was more concerned with showing that Stephens "was one of the least denunciatory and vehement of the public men of distinction with whom he laboured" than with exploring his contribution to Chartism. ${ }^{1}$ Neither R. G. Gammage nor Mark Hovell clearly raised either question. ${ }^{2}$ Julius West noted that Stephens "always denied that he was a Chartist himself" but nonetheless had no hesitation in asserting that Stephens spent his energies supporting "Chartist principles" and the Charter. ${ }^{3}$ West drew largely on the Place Collection - a source hostile to Stephens - and not surprisingly viewed the influence of Stephens (and of Feargus O'Connor) on the movement as "deplorable": "They had introduced foreign elements into Chartism." 4 Max Beer, in contrast to West, thought that Stephens could not "be regarded as a strict adherent of the Chartist movement". Beer saw Stephens's "main object" as "the repeal of the new Poor Law and the improvement of the material condition of the working people", but he thought, "the Charter seemed to him to be a fit means to this end". ${ }^{5} \mathrm{He}$ was not concerned with Stephens's impact on the movement. Rosenblatt devoted a section of his book to Stephens's rhetoric on physical force, but he did not compare closely Stephens's views with those of other Chartists. He did note that Stephens, "contrary to well-nigh all Chartists [...] never made universal suffrage synonymous with universal happiness". He suspected that Stephens "in his heart of hearts [...] probably never believed in the efficacy of political agitation". ${ }^{6}$ G. D. H. Cole, in his chapter on Stephens in Chartist Portraits, addressed himself to the question of why he abandoned the movement and concluded that Stephens was at home in the early Chartism "of instinctive uprising of the people against intolerable oppression" but had no interest in it as a political movement. ${ }^{7}$ In a few brief sentences, Schoyen throws

1 George Jacob Holyoake, Life of Joseph Rayner Stephens: Preacher and Political Orator (London, 1881), pp. 97, 146, 232, 102-103.

2 R. G. Gammage, History of the Chartist Movement: 1837-1854, 2nd ed. (New York, 1894, reprinted 1969); Mark Hovell, The Chartist Movement, 2nd ed. (Manchester, 1925).

${ }^{3}$ Julius West, A History of the Chartist Movement (New York, 1968), pp. 91, 96.

4 Ibid., p. 126.

5 Max Beer, History of British Socialism (London, 1921), II, p. 16.

- F. F. Rosenblatt, The Chartist Movement: In Its Social and Economic Aspects (New York, 1916, reprinted 1967), pp. 128-129. Hermann Schlüter makes the same point based on the evidence of the political sermons of 1839 , in Die Chartisten-Bewegung. Ein Beitrag zur sozialpolitischen Geschichte Englands (Stuttgart, 1922), P. 98.

7 G. D. H. Cole, Chartist Portraits (London, 1941), p. 79. 
much more light on Stephens by contrasting him with George Julian Harney:

"Where his speech differed fundamentally from that of Stephens was in its emphasis on political power. To the passionate exponent of resistance to the New Poor Law, political change was incidental - the real remedy for distress lay in the spiritual regeneration of the upper classes. To Harney, the seizure of the state was primary."1

On the other hand, Read and Glasgow never explored the crucial relationship between O'Connor and Stephens, nor did they compare the views of the two men. ${ }^{2}$ Both Cecil Driver and Nicholas C. Edsall - approaching Stephens from the perspective of the anti-Poor Law movement rather than from Chartism - were aware that his commitment to the protest against the New Poor Law was much greater than his adherence to Chartist solutions. ${ }^{3}$ And J. T. Ward has agreed that "Stephens entered the movement, but on his own terms and for his old aims". "But Ward - like Driver and Edsall - was not concerned with Stephens's impact on the Chartist movement.

None of these historians noted that Stephens explicitly stated his reservations about the Chartist agitation at the very outset of his participation. He said that he did not believe that the five points of the National Petition would lead to a substantial improvement in the condition of the working men, and that he did not like the "moral force" course of agitation plotted by the leaders of the Birmingham Political Union. Because he had no commitment to the means or the ends of the Chartist movement, Stephens's participation proved divisive. By asserting strongly his belief in the efficacy of "physical force", he did much to change the shape of early Chartist agitation. His advocacy of "physical force" reached a wide audience because of his fame, his popularity with the working men, his connection with the Northern Star, his commanding ability as a public speaker, and his ability to confirm the worst fears of the middle class. With O'Connor, he was largely responsible for undercutting the strategy of the Bir-

1 A. R. Schoyen, The Chartist Challenge (London, 1958), p. 38.

${ }^{2}$ Donald Read and Eric Glasgow, Feargus O'Connor: Irishman and Chartist (London, 1961).

${ }^{3}$ Cecil Driver, Tory Radical: The Life of Richard Oastler (New York, 1946), pp. 396-7; Nicholas C. Edsall, The anti-Poor Law movement, 1834-44 (Manchester, 1971), pp. 182-185.

4 J. T. Ward, "Revolutionary Tory: The Life of Joseph Rayner Stephens of Ashton-under-Lyne (1805-1879)", in: Transactions of the Lancashire and Cheshire Antiquarian Society, LXVIII (1958), p. 103; this article (pp. 93-116) is the best piece of work on Stephens. 
mingham leaders, and they were denounced in turn by the moral-force leaders. O'Connor tried to reach an understanding with the leaders of the Birmingham Political Union, but Stephens - committed more to "physical force" than to the Chartist movement - made it impossible for them to reach any lasting compromise. As a result, the movement was split before the Convention of 1839 met. Even after he retired from the agitation, Stephens left his mark on the movement. His espousal of "physical force" helped to establish a following on which Harney and his allies could rely for support. Stephens's connection with O'Connor made it difficult for O'Connor to convey to the country that he had a very different strategy than Stephens. And Stephens's rhetoric and presence on Chartist platforms played a part in shaping an image of the movement that hurt the Chartists.

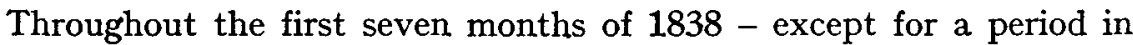
April and early May when he was beset by "domestic afflictions"1 Stephens was a prominent speaker at meetings in the North called to oppose the New Poor Law or to assist the Glasgow Cotton Spinners. But he did not come to Chartism eagerly. After attending one Chartist demonstration (at Keighley on 30 July), he was absent from public meetings until 15 September when he was elected by his fellow citizens of Ashton-under-Lyne as their delegate to the forthcoming Chartist Convention. Arriving after the election had taken place, he told his audience that he had been "standing aloof" from Chartist agitation for two reasons. First, even if they were successful in carrying the Charter, "the scheme would be abortive, for it was in the great question of capital and labor and its proper arrangements that were concentrated the future welfare of the laboring millions". Second, he had stood aloof because "he was for physical force, and the promoters of this question were for moral force; they were for petitioning and in that he could not join them". Although he would not sign the petition, he would "obey their summons" and help the men of Ashton obtain universal suffrage if they wanted it. He stipulated only that they must grant him the freedom to express his own opinions in his own terms. Upon his request that the meeting vote again on whether they wanted him to serve as their delegate, he was again elected "almost unanimously". ${ }^{2}$

Northern Star, 21 April 1838, p. 6. Perhaps one cause of his temporary retirement was his stay with Richard Oastler when Oastler was convalescing from a nervous breakdown. See C. Driver, Tory Radical, p. 378.

2 Manchester \& Salford Advertiser, 22 September 1838, p. 3. 
It was natural for the men of Ashton to honor Stephens by electing him as their delegate to the Convention. For many years past, he had been their foremost champion; he had become known and respected far beyond the confines of the immediate area. His advocacy of factory legislation and his opposition to the New Poor Law had won him the gratitude of the working men. And Stephens did not hesitate to claim that gratitude, reminding his audiences that he had sacrificed "his time and his money in advocating the cause of the oppressed" and that he had given up "bright worldy prospects [...] personal comforts and conveniences and all that was at present considered honorable and respectable in society".1 There was some truth to the claim. He was born in 1805, one of twelve children of a Methodist minister. It was a family of some distinction: the father was once elected President of the Wesleyan Conference, one of Stephens's brothers was a banker, another a newspaper publisher, and a third held the chair of English literature at the University of Copenhagen and won high regard for his scholarship. Stephens himself was well educated and spoke several languages fluently. He followed his father into the Methodist ministry, serving at Stockholm before coming to Ashton. In 1834 he lost his church and his place in the Methodist Connexion, but the support of the working men allowed him to stay at Ashton and to continue preaching. Mutual dependence of minister on flock and of operatives on orator increased the efforts of each on behalf of the other.

When Stephens talked of the relationship between capital and labour, between employer and employee, he was looking toward a society in which the nexus was not cash but responsibility. He wanted the working man "to meet his master and stand boldly, and upright upon his feet, without the brandmark of a bondsman upon his brow, and without the blush of shame and of slavery upon his cheek". ${ }^{2}$ As he told an audience at Macclesfield, "all were trained up and taught to do the best they could for themselves, and to care nothing about their neighbour". Selfishness had become "the predominant power that everywhere ruled the actions of men", and wealth, however acquired, "the only standard of respectability". Instead, men should be ordered by "social rights and social duties, everywhere equally sacred in the sight of God - everywhere of equal obligation upon all men, one towards another". 3 Such a relationship could not be brought about by legislation but would have to grow naturally. It was rooted in the old concept of mutual interests between social "orders", or in

1 Northern Star, 17 February 1838, p. 3.

2 Ibid., 29 September 1838, p. 6.

${ }^{3}$ Ibid., 6 October 1838, p. 6 . 
his balanced phrases, of "the rich bearing the burdens of the poor and the poor bearing the burdens of the rich". ${ }^{1}$ Most Chartists, however, differed from Stephens in thinking that the rich would ever again willingly shoulder their responsibility to the working men. They saw no end to oppressive class government and exploitative class relations until the working men were represented in the House of Commons. Hence their support for the People's Charter, which Stephens rarely mentioned and in which he had no faith. But despite the differences of approach, both Stephens and the Chartists could agree upon the ultimate goal: a good life for the working man.

When Stephens described the good life for the working man, it was in terms unmatched for their appeal. He avoided utopian visions for a down-to-earth picture, complete with affecting details, of what their life should be:

"I know full well that our frail flesh is heir to many ills; all I ask for is, that the poor should have it in their power, when God visits them with affliction, to enjoy those consolations which he has offered them. That is all. Your children will have the measles, the smallpox, the typhus fever, I cannot hinder it when it comes; but a great deal of it might be prevented. (Hear, hear.) For when does it come? Hardly ever but when starvation comes before it $[\ldots]$ and when it does come, all $I$ ask for them is, that the mother shall have it in her power to go to the apothecary's and confectioner's, and buy the drug at the one shop and the currant juice at the other, and give the medicine, so that at all events the poor dying child may expire with as little possible pain, and with the smile of affection upon its lips." 2

1 Ibid., 17 November, 1838, p. 6. In making such statements, Stephens was drawing on a long and rich tradition of English social thought and popular social attitudes. Both the labouring poor on the one hand and elements of the gentry and nobility on the other hand subscribed to it. For an analysis primarily drawn from behavioural evidence of popular attitudes among the working people, see E. P. Thompson, "The Moral Economy of the English Crowd in the Eighteenth Century", in: Past \& Present, No 50, (1971), pp. 76-136. Harold Perkin used literary evidence in his examination of the social thought of the nobility in The Origins of Modern English Society, 1780-1880 (London, 1969), pp. 237-252. David Roberts has pointed out forcefully that this line of thought did not lead to effective legislation, "Tory Paternalism and Social Reform in Early Victorian England", in: American Historical Review, LXIII (1958), pp. 323-337. For the translation of the popular attitudes into articulate protest, see E. P. Thompson, The Making of the English Working Class (London, 1963). Stephens was not the only popular leader who held to an old ideal of mutual responsibility; his ideas were remarkably similar to those of Richard Oastler. See Cecil Driver, Tory Radical.

2 Northern Star, 17 November 1838, p. 6. 
According to Stephens, God intended that man should work at a "fair day's wage for a fair day's labour" and thereby earn enough to provide for his old age. A working man should have a living even if he cannot find work or he has no strength left to labour. And when death came, his widow should have kindness and sufficient support rather than be put away in the "Poor Law Bastile". ${ }^{1}$ His vision gave the labouring man a dignity that would be reflected in his home life. $\mathrm{He}$ would again assume his place at the head of the family, earning the bread which his wife would bake. The husband, "not the mill owners [...] not the Poor Law Commissioner", would rule over his wife. Stephens maintained that despite "all the interested, detestable, and damnable doctrines of the Whig political economists", a woman was made to be a companion and mother. The woman's factory was in the kitchen, and her desire was to be with "those dear babes, sweet pledges of love and tokens of God's benevolence". As Stephens told his audiences, "it is shown even from the Bible that Grod meant man to be middling-like happy". ${ }^{2}$

Stephens may have embroidered his picture of the good life in much greater detail than Chartist orators, but all held basically the same idea of what constituted the good life. The twin elements of physical comfort and human dignity appealed to the Chartists as much as to Stephens. And his attitude toward universal suffrage was like theirs in two respects. He agreed both that the franchise was a basic right of every man and that possession of the suffrage was important as a symbol of dignity. He felt that every man

"of full age, of right mind and of unblemished life, had the same right to come where his neighbours came, to speak where his neighbours spoke, to hold up his hand for the same things for which his neighbours held up their hands, and [...] if of the majority, to decide and determine, and if of the minority, to acquiesce peaceably and loyally in the decision."3

But Stephens failed to see the importance of altering the nature of the "majority" and was not, therefore, as concerned with acquiring universal suffrage as the Chartist leaders were. Stephens might claim that the principle of universal suffrage had "ever been dear to his heart", but such statements constituted the extent of his advocacy in 1838. As he put it in July, 1839, when he again explicitly stated his differences from the Chartists in his "Last Sermon", he supported universal suffrage "only [...] in a certain sense, and with certain

1 Ibid., 20 October 1838, p. 7; 17 November 1838, p. 6.

2 Ibid., 17 November 1838, p. 6.

3 Ibid., 29 September 1838, p. 6. 
limitations". And in 1838, Stephens did not even mention the other points of the People's Charter, nor did he refer to the document itself. His principal reference to the National Petition in 1838 was to say that he would not sign it; while in his "Last Sermon", he said that he "did not care two straws about the five points". ${ }^{1}$ He did not accept the Chartist premise that once they had the Charter everything else would follow, including repeal of the New Poor Law and of the corn laws. And while the Chartists concentrated on obtaining the Charter, Stephens directed his fire against the New Poor Law.

The other point of difference from the Chartists that Stephens noted centered around the use of physical force. Stephens did not hesitate to preach the legitimacy of the use of force. His strongest reported statement from a Chartist platform was made at Wigan, where he asked the audience whether they had ever heard a man "that put clearer words in a straighter row, with a stronger or a bolder front before the people of England". Encouraged by their response, he said he had come to tell them it was right not only to have arms in their homes, and in their hands if necessary, but also it was right actually to use them

"for the very purpose for which they were made, for the reason why God gave us cold lead and sharp steel was to put an ounce of the one, and six inches of the other into the bodies and brains of any men, and of all the men [...] call them magistrates if they liked, or Commissioners, or Powers, or principalities, or thrones".2

For Stephens, the legitimacy of the use of force in resisting the New Poor Law rested on the twin pillars of the Scriptures and the constitution. Related to these arguments - and partaking of both - was his notion of the reciprocal relationship of responsibility with the rich bearing the burdens of the poor and the poor bearing the burdens of the rich. According to his interpretation of the Scriptures, the earth had been made over from God to man "in fee simple" for certain uses and interests. Furthermore, God had set a standard by which laws were to be judged, and that standard was "justice, kindness, and brotherly love". The existence of an eternal standard was essential to Stephens for it provided a way in which he could judge the laws of the realm with absolute certainty. As he told an audience at Carlisle in October: "It is mere humbug to drill the people into the unconstitutional notion that they should obey all laws, whether they be good or whether they be bad. The principle is anti-political, antisocial, and anti-Christian."3

\footnotetext{
1 Ibid., 17 August 1839, p. 6.

3 Ibid., 27 October 1838, pp. 5, 6.

2 Ibid., 17 November 1838, p. 6.
} 
Almost as important as the Word of God to Stephens in establishing a basis for passing judgment upon the present laws were the ancient constitution of the country and the old English ways of doing things. They underlie the question he posed at Wigan: "Whether it is not high time to destroy that law, which destroys the feelings and breaks the heart, and desolates the entire face of this once happy but now a miserable and wretched people?" According to him, their forefathers had established "land marks of law - land marks of right, land marks of liberty", only to have the country lose sight of them. The time had come to recover them and to reclaim "old rights". Stephens's speeches are rife with references to the Magna Carta and the "good old laws of English freedom - free meetings - freedom of speech - freedom of workshops - freedom of homesteads - free and happy firesides and no workhouses". ${ }^{1}$ Here was a set of flexible and pliant myths which served other radicals as well as Stephens.

His purpose in advocating "physical force" seems to have been part of an attempt to convince the government not to introduce the New Poor Law into the North. ${ }^{2}$ Violent language also proved an effective method of rallying support against the New Poor Law; it offered the working men a symbolic outlet for their frustrations and aggression - an outlet safer though perhaps less satisfying than other forms of action. Stephens also may have been deliberately courting arrest and trial for resistance to the New Poor Law, so that its legality could be tested in the Courts. ${ }^{3}$ Certainly his advocacy of arming was related to the fundamental goal of aiding the working man to regain his lost dignity. In a letter published in the Northern Star on 22 December, 1838, Stephens said that "the badge of a bondsman was the

1 Ibid., 20 October 1838 , p. 7.

2 This discussion of Stephens's advocacy of "physical force" does not take into account his emotional needs, which must remain highly conjectural. Over and above Stephens's inherent aggressiveness, his talk of arming and of "war to the knife" may have offered some satisfaction to him personally, for it gave him emotional stature in his personalised confrontation with the powers of darkness embodied in New Poor Law officialdom. They could not take him for granted if he could call forth a whole host of redressers. More certainly an element in Stephens's vehemence was that the New Poor Law represented in his eyes a fatal blow to the old world of mutual dependence - a blow struck by the landowners, who were the only hope for maintaining the old relationship. Because the New Poor Law undermined the basis of his entire social thought and justification, Stephens attacked it with all the vigour and apparent disproportion of an intellectually and emotionally threatened man.

${ }^{3}$ Robert Lowery suggested this possibility in his autobiography in the Weekly Record, 16 August 1856, p. 170. However plausible the idea may be as an explanation for Stephens's behaviour, it certainly has not been mentioned by modern historians of the agitation against the New Poor Law. 
print of the lash upon his naked back - the mark of a freeman the trusty sword hung over the door-post of his castle-cottage". Magistrates, factory owners, and overseers would not treat with contempt a man with a pike in his hand. The trusty sword over the door-post served both as a symbol of dignity and as a means of regaining it. At times Stephens seemed to preach "a revolution in favour of truth and righteousness through the spirit of God and by means of the right arms of men", as he said at Wigan. But while he advised men to fight to resist the New Poor Law or to resist "attack", he did not advise them to "War to the Knife" for the People's Charter. Indeed, in his "Last Sermon", he claimed: "I have always told you that Universal Suffrage, Annual Parliaments, Vote by Ballot, and all the rest of the rigmarole, was not worth fighting for." And he went on to assert "one thing I know is, that you can't get it by fighting for [it]. I know you can't fight and win".

Stephens was not out of the mainstream of the Chartist movement simply because he advocated "physical force". All Chartist leaders agreed that the people had an abstract right to resist tyranny by arms if necessary: the Revolution of 1688 had established that right. Nearly all Chartist leaders agreed about the legitimacy and legality of arming. In April, 1839, the Chartist Convention declared that the right to arm "is established by the highest legal authority, beyond all doubt." 1 But some Chartists doubted the wisdom of advocating arming or of loudly proclaiming the right of resistance. Many Chartists joined Stephens in relating arming to an assertion of dignity. And a few agreed with him in the legitimacy of the use of force and in the practicality of proclaiming it. But even they differed fundamentally from Stephens in their conception of what force would achieve. Behind the Chartist concern with force lay a search for a strategy to carry the Charter. Stephens was not interested in the Charter or in the means of enacting it; he linked force not to gaining the Charter but rather to resisting the New Poor Law. Yet many Chartists, who did not understand Stephens's lack of interest in the Charter, adapted his advocacy of force to a strategy for Chartist success. They were able to think in these terms because Stephens had built up a great deal of support by his advocacy of force. It was here that he had his greatest impact upon the movement.

In assessing Stephens's impact on the Chartist movement, it is essential

1 Sun, 10 April 1839, p. 3; Charter, 14 April 1839, pp. 188-189; Northern Star, 13 April 1839, p. 1. 
to understand the attitudes of the Chartist leaders toward force. Stephens told the men of Ashton that one reason he had been standing aloof was this very question of force. "The promoters of this question were for moral force", he said. This view seems natural because the men of the Birmingham Political Union put forward not only the plan of the agitation - with the National Petition and the Convention but also a strategy based on "moral force". They used the Reform agitation as the historical model for their strategy and interpreted the success of 1832 as the result of class cooperation and economic pressure ("To Stop the Duke, Go for Gold"). For Chartism, they proposed that economic pressure be applied by abstinence from exciseable articles, by withdrawals of money from savings banks, and by hoarding gold. These predominantly middle-class leaders did not neglect class cooperation, and they encouraged middle-class sympathisers by emphasizing that the agitation would be peaceful, legal and orderly. The strategy of moral force and economic pressure was endorsed by the early entrants into the agitation: the leaders of the London Working Men's Association and leading Scottish radicals.

Only one other strategy was put forward in the summer of 1838 . It was brilliantly advocated by $\mathrm{O}^{\prime}$ Connor who thought that economic pressure would not be sufficient to bankrupt the Treasury. He thought, rather, in terms of intimidating the government by displays of overwhelming mass support and preparedness. Like the advocates of economic pressure, O'Connor based his strategy on the historical model of the Reform agitation, adding Catholic Emancipation to it. He interpreted these victories for reform as the result of the Government's recognition of the fact that it could not control the country, that the agitation had gotten out of hand and could only be allayed by concessions, not by resistance. ${ }^{1}$ The strategy of intimidation did not rely on either class cooperation or economic pressure but rather on the mass support of men willing to threaten violence if balked. Treading a fine line between generating support and holding it in check, O'Connor did not advocate arming in the summer or autumn of 1838, but he engaged in some aggressive sloganeering; such as it is better "to die free than to live a slave".2

1 Another model must have been the agitation against the New Poor Law which O'Connor had joined - with Stephens, Oastler, and others - and which had successfully delayed implementation of part or all of that hated Act in areas of the North for some time by the autumn of 1838 . O'Connor did not point to it as a model for Chartist strategy, however, as he did to the Catholic Emancipation and Reform agitations.

2 For a discussion of the position of O'Connor and Chartist strategy, see Thomas Milton Kemnitz, "Approaches to The Chartist Movement: Feargus O'Connor and Chartist Strategy", in: Albion, V (1973), pp. 67-73. 
Richard Oastler was the only prominent leader of the working men who advocated arming and drilling in the late summer of 1838. But his involvement in the agitation was limited to letters printed in the Northern Star in August and September and to an appearance on the fringes of the South Lancashire demonstration in September. Moreover, he was not presenting a strategy for obtaining the enactment of the Charter. Stephens became much more active than Oastler in advocating arming when he began his Chartist career in mid-September. Stephens, Oastler, and O'Connor were quickly lumped together as advocating "physical force", despite obvious differences: Stephens and Oastler advocated arming, but O'Connor did not; O'Connor advocated a strategy for gaining the Charter, but Stephens and Oastler did not. Together, they commanded national attention and thoroughly alarmed the Birmingham leaders. For whatever the differences between them, they all undercut a strategy based on class cooperation by frightening away potential middle-class supporters. By the end of October, after Stephens had been agitating for six weeks, R. K. Douglas and T. C. Salt of Birmingham were so perturbed that they attacked "the advocates of physical force". ${ }^{1}$

The reactions of O'Connor and Stephens were an indication of their commitment to the Chartist movement. O'Connor journeyed to Birmingham where he spent several days during the last three weeks of November trying to settle the differences amicably and attempting to hold the movement together. He made peace on the best terms he could. He did not abandon his strategy of forceful intimidation, and he did not hesitate to criticise the strategy of moral force. But he joined the Birmingham leaders in a denunciation of physical force, although he would not denounce Stephens. Meanwhile, Stephens accomplished his different purpose and undermined O'Connor's efforts by staying away from Birmingham and by denouncing the "old ladies in breeches". While O'Connor risked his popularity, Stephens increased his with defences of arming and the right to use force, couched in increasingly vivid language. In doing so he built up a solid opposition in the North to the Birmingham strategy and rallied great support for the policy of arming. ${ }^{2}$

1 Birmingham Journal, 3 November 1838, p. 3.

2 For his success in convincing the men of the North, see the Leeds resolution in the Northern Star, 1 December 1838. Leeds was O'Connor's stronghold, but the resolution paraphrases part of Stephens's Wigan speech printed in the Star of 17 November. For further evidence, see ibid., 8 December 1838, the Leeds resolutions (p. 1), the Stalybridge address "To the Council and Members of the Birmingham Political Union" (p. 1), and the Ashton resolutions (p. 5). Stephens's influence on the subsequent addresses and resolutions must have been great, 
Stephens's success in convincing the men of the North depended upon his enormous ability on the platform. He was both dramatic and eloquent, effectively adapting the minister's vocabulary and mode of expression to the worker's cause. He stated the situation in simple terms that working people could understand. He created for them a picture of a happy, pastoral life, disturbed not so much by the machine as by a new class of men created by the machine. He had a villain whom they could identify: the factory owner and his ally, the Poor Law Commissioner who broke up homes, tearing wives from their husbands and children from their parents. He then conveyed to each listener a picture of himself with a pike in his hand fighting off the villain. It was a picture which offered both dignity and vengeance. Then, as if to present the rewards of this course, Stephens turned the scene from violence to a peaceful, happy vision of wife and children by the fire.

O'Connor was fully aware of Stephens's power as an orator and his popularity with his audiences; he could not have wished to challenge the one man who rivalled him in both. O'Connor wanted to hold the movement together and to increase it as much as possible, and he was using Stephens's reputation and following to bring the working men of the North into the Chartist movement; fighting with Stephens would have split the movement at its strongest point. Moreover, Stephens was part of the foundation on which the circulation of O'Connor's Northern Star was built; a fight with Stephens would have hurt the sales of the paper, which sold well in the areas where he was popular. ${ }^{1}$ Perhaps, too, O'Connor calculated that in attempting to carry out the terms of the compromise in the North he could be forced to take an unpopular stand or would at least miss taking a

but it is impossible to separate his from O'Connor's because O'Connor came out in favour of arming in the Star on the 15th and because both were being supported together with Oastler against the attack of Daniel O'Connell on them. A Loughborough magistrate in January, 1839 attributed arming in his area to Stephens's speeches; see J. F. C. Harrison, "Chartism in Leicester", in: Asa Briggs (ed.), Chartist Studies (London, 1959), p. 102.

1 The connection between the Star and Stephens was very close. Stephens had taken $£ 20$ worth of shares when the paper was established (G. J. Holyoake, Life of Stephens, p. 181). The paper had built up its circulation by giving full coverage to Stephens. The most blatant use of him by the Star was soon after his arrest when the Star announced on 19 January (p. 1) that in February it would publish an issue on "superfine paper" and include in it a full length portrait of Stephens "worth One Guinea" and a biography "of the Glorious Champion". The price to subscribers was to be six pence, but the price to nonsubscribers was to be $£ 11 / 6 d$. In 1839 Stephens was appointed a sub-editor of the Star to write up his sermons for publication. They were published in the regular issues of the paper and also separately as a series of pamphlets. 
popular position. At any rate, O'Connor was caught: Stephens had made it impossible for him to hold easily the Chartist associations of the North in any sort of compromise. And Stephens had further undermined the compromise by picturing O'Connor as the challenger of the Birmingham leaders. Faced with the prospect of splitting the Chartist ranks in the North, O'Connor chose not to fight Stephens. Instead, in mid-December - two weeks after reaching agreement in Birmingham - he adopted Stephens's position of advocating arming, citing as an explanation the desire of the Birmingham men to form an alliance with the detested Daniel O'Connell. Stephens thus had succeeded in carrying at least part of his position; it remained for O'Connor to consolidate it.

Ironically, Stephens chose this time to announce that he would not attend any more public meetings. Aware of rumours that the authorities wanted to arrest him and that he was being widely blamed for the burning of a mill at Ashton, he stopped attending meetings by the middle of December. But his torchlight rhetoric had frightened too many people for the authorities to risk a renewal of his agitation. $\mathrm{He}$ was arrested on 27 December for attending an illegal meeting in November. Quickly released on bail, he became something of a martyr; addresses to him were sent by Chartists all over the country, and a defence fund was established to aid him. He resigned his seat in the Convention, and his place for Ashton-under-Lyne was taken by his nominee, Dr Peter M. M'Douall. During the spring of 1839, he travelled around the country delivering political sermons. He dropped in on the Convention. But Stephens's Chartist career ended rather badly. In June M'Douall publicly accused him at Ashton of making improper advances to a young lady. (She was the unmarried sister of Bronterre O'Brien's wife; M'Douall had introduced her to Stephens.) It was not at all the sort of thing which was acceptable for a married man who was also a minister popular for his defence of the sacredness of the home and the marriage tie. The ensuing scandal bitterly divided the Ashton Chartists during the summer of 1839 , but that meant little to Stephens, who denied all connection with Chartism, particularly in his sermons preached in July as well as in his defence at his trial in August. Nevertheless he was found guilty and sentenced to eighteen months in prison. In 1842 he was shouted down by the Chartists when he supported a Tory candidate at a Nottingham by-election.

\section{III}

Stephens's most important contribution to Chartism lay in helping to arouse the men of the North of England, in encouraging them to 
develop a sense of their grievances, and in reinforcing an identity on which the Chartist could draw. This contribution did not cease when he stopped appearing on Chartist platforms in December, 1838. His political sermons - printed first in the Northern Star and then published in pamphlet form - served the same purpose, and the Chartists regarded them as one of the most effective means of winning adherents. In April, 1839, Abram Duncan told the Convention of selling nearly 3,000 of Stephens's sermons on a missionary tour of Cornwall:

"I am convinced that those sermons have done more good than ten thousand speeches. (Cheers.) It was the first document which taught the people their religious right to freedom, and well assured am I, that it Stephens was five months in Cornwall, he would rout all the Methodist parsons from the country". ${ }^{1}$

And Marsden wrote to the Star of his visit to Ireland in May, 1839: "Much did I wish that I had but a few hundred of your Northern Star to distribute, with as many of the sermons of our beloved Stephens they would create a not easily allayed ferment in that ill-fated country's stagnant social pond." 2 The sermons also offered working men a highly literate and effective alternative to the organised religion of their political enemies, and they were read aloud at Sunday gatherings throughout the country.

Stephens, moreover, played a part in the development of a physicalforce strategy, although it would be incorrect to see him as its leading spokesman. The coherent strategy for gaining the Charter by violent confrontation, which emerged in 1839, was put forward by George Julian Harney and some of his allies in the Convention. It was based on the French Revolution as an historical model and looked toward a general strike - the sacred month - to provide the conditions in which the confrontation would take place. This was not the currency in which Stephens had dealt. But at its base lay an extension of his ideas about resistance to bad laws. Stephens had circulated the ideas through the movement; all the weight of his reputation and his ability to command attention in the press - including the Northern Star - had helped in gaining a following for them. Harney and his allies were thus indebted to Stephens for gaining enough support for their strategy to be considered at all seriously. And at the local level, Stephens's rhetoric was important in encouraging Chartist associations to favour a policy of arming and to reject the strategy of the leaders of the Birmingham Political Union. The enormous support Stephens received after his

1 Northern Star, 13 April 1839, p. 1. High praise.

2 Ibid., 8 June 1839, p. 8. 
arrest gives some idea of his wide-spread popularity among rank-andfile Chartists. ${ }^{1}$

Stephens also notably influenced O'Connor by hurrying him into advocating arming. O'Connor was clearly caught in December between his compromise with the Birmingham middle-class leaders and the popularity of Stephens's position. When the Birmingham leaders welcomed Daniel O'Connell's Address - which attacked O'Connor, Stephens, and Oastler - O'Connor broke his side of the compromise and attacked them. His attack came along the lines of Stephens's position in advocating arming, and O'Connor brilliantly undermined the advocates of moral force within a month in their three strongholds of Birmingham, London, and Scotland. The result was that the Chartist Convention met in February, 1839 in an atmosphere of tension, and the Birmingham advocates of peaceful pressure were among the first to withdraw from it. ${ }^{2}$ This chain of events began with Stephens.

Stephens's well publicised statements on force, together with the chain of events described above, also undermined O'Connor's effort to get across his strategy of intimidation. In the eyes of the public - both Chartist and non-Chartist - he became associated with Stephens. $\mathrm{He}$ tried to point out the differences between them ${ }^{3}$ but was not very successful. O'Connor's difficulty resulted from conceptual restraints imposed by the dichotomy between moral and physical force. The very terms "moral force" and "physical force" implied only two strategies; O'Connor was putting forward a third one. But few realized his position. He probably would have made the point had he denounced Stephens, but this he could not and would not do. So O'Connor was labelled a "physical-force advocate" - an image which has continued to colour much of the writing about him.

Stephens's rhetoric caused problems for more than just $O^{\prime}$ Connor, for it undercut the strategy of moral force and economic pressure by frightening away potential middle-class supporters. ${ }^{4}$ And it aided the

1 One test of his popularity was the money raised as a defence fund for him. By the end of July, 1839, nearly $£ 600$ had been collected, about half as much as the total National Rent collected to support the Convention (Northern Star, 27 July 1839, p. 5).

2 R. K. Douglas, Benjamin Hadley, and T. C. Salt did not attend the Convention after 27 February; John Pierce attended his last session on 11 March. Such men as J. P. Cobbett, Patrick Matthew, and Dr Wade joined them in withdrawing from the Convention before the end of March.

${ }^{3}$ See his speech at Leicester reported in the Leicestershire Mercury, 24 November 1838, p. 1.

1 R. K. Douglas of Birmingham, William Lovett, and the Calton Hill resolutions passed in Edinburgh in December, 1838 all made this point; see the Birmingham Journal, 31 November 1838, p. 3; the Northern Star, 29 December, 1838, p. 8, and 15 December 1838, p. 7. 
opponents of Chartism in picturing it as a violent movement. ${ }^{1}$ Here the conjunction of Oastler, Stephens and O'Connor in September was important, for the three had gained a large measure of national notoriety in their not always peaceful opposition to the New Poor Law. It left the Chartist movement open to presentation as a successor in spirit and tactics to the earlier agitation. ${ }^{2}$ And Stephens's vivid language reinforced this image throughout the autumn. The result was that Chartism was presented in middle-class newspapers in these terms: "This is not, nor has it ever been considered, a question of abstract justice, but one of expediency and might."3 In assisting in large measure in making such a view seem reasonable, Stephens certainly hurt the Chartist agitation with middle-class audiences, for the Chartists had lost much when they were viewed in the harsh light of "expediency and might" rather than in the sympathetic light of justice and natural rights in which they represented themselves. Hostility to them thus became fixed without any consideration of the case they made.

${ }^{1}$ For attacks in papers which were not invariably hostile to the working men, see Leicestershire Mercury, 8 December 1838, p. 3; London Dispatch, 2 November 1838 , p. 921 ; Silurian, 29 November 1838, p. 3; Weekly True Sun, 16 December 1838, p. 2212.

2 For editorials linking Stephens, O'Connor and Oastler see the London Dispatch, 7 October 1838, p. 875; Preston Observer, 1 December 1838, p. 2; Shrewsbury News, 15 December, 1838, pp. 166-167; Brighton Herald, 16 March 1839, p. 4; for another example see Daniel O'Connell's reply to the LWMA Address to the Irish People, printed in the Northern Star, 8 December 1838, p. 8.

${ }^{3}$ British Museum, Place Collection, Set 56, Vol. III, f. 89. 